\title{
The Effect of Electronic Banking in Financial Supply Chain: E-Banking in Eritrea
}

\author{
Gvozdanovic I* and Solomon OM \\ Department of Finance, Zagreb School of Economics and Management, SMC University, Switzerland
}

\begin{abstract}
Information technology is fundamentally changing the banking industry and financial supply chain activities worldwide. While the advent of e-banking offers banking firms a new frontier of opportunities and challenges, it is also revolutionizing the way business is conducted in every industry. Banks, corporations, governmental agencies and other financial institutions in Eritrea are not exceptions to this transformation. This study aims at examining the effect of e-banking on the banking industry as well as its influence on financial supply chain; if Eritrea is to adopt modern banking system. The study was based on qualitative approach and two types of interview guide questions were administered to some selected bank officials of the four banks and bank customer company managers using purposive and unstructured interviewing techniques. Findings from the study indicate that e- banking services in Eritrea are not yet initiated. The adoption of modern banking systems is believed to solve existing challenges in the banking industry, in the financial supply chain and in e-business as a whole.
\end{abstract}

Keywords: Financial supply chain; e-banking adoption; e-banking infrastructure

\section{Overview}

Even though there are different definitions of the term financial supply chain, which appeared for the first time in 2000 and 2001, Popa et al. [1] described it as it "parallels the physical or materials supply chain and represents all transaction activities related to the flow of cash from the customer's initial order through reconciliation and payment to the seller". In other words, the financial supply chain is different from the physical supply chain, because it deals with the flow of cash instead of goods. While, the purpose of FSC is to obtain visibility over the purchase-to-order and order-to-cash processes [2], the role of financial supply chain management is simply to manage the financial supply line, now interconnected as a chain, from source to destination and back [3]. It is about looking at how to optimize working capital of a company, not only from an internal point of view, but also from an external point of view [4].

When companies move from regional to global sourcing their working capital and supply chain performance is negatively affected, due to shipment and payment delays [5]. In resolving this issue, financial designers of the organizations put their attention on their banks to optimize their financial supply chains which could be provided by e-banking system. According to Sarma et al. [6] e-banking refers to systems that enable bank customers to access accounts and general information on bank products and services through a personal computer or other intelligent devices. Supply Chain Finance (SCF) gives trade banks the tools they need to align their offerings with their customers' evolving supply chain needs [7]. It describes the activities involved in planning and executing payments between trading partners [8]. The overall goal of SCF is to optimize working capital throughout the end-to-end supply chain for both buyers and sellers.

\section{Profile of the Banks in Eritrea}

Modern banking in Eritrea started with the arrival of the Italian colonizers. However, from 1974 on, due to the nationalization decided by the Ethiopian government, the banking sector became a government monopoly. This situation continued after Eritrea achieved its independence in 1991. The bank of Eritrea is the central bank of Eritrea. At present there are three commercial banks in operation in
Eritrea - the commercial bank, the housing and commercial bank, and the Eritrean investment and development bank [9]. All banks with the exception of the housing and commercial bank are under state ownership, while the housing and commercial banks is owned by the ruling party, the People's Front for Democracy and Justice (PFDJ) [10]. All the banks are headquartered in the capital city-Asmara.

\section{National bank of Eritrea}

The bank of Eritrea is the country's apex bank and its principal objective is to manage money and credit in the economy. Since independence, the bank has assumed all functions of a central bank including: the regulation and supervision of financial institutions, the issuance of bank notes and coins, advisor banker, and fiscal agent to the government of Eritrea, determination of the exchange rate system for the Nakfa (national currency), acceptance of deposits from and provision of advances to depository institutions, influence of the supply of money and credit in the economy, and regulation of rates of interest and foreign exchange [11]. It tries to facilitate financing in the supply chain specifically for international transactions.

\section{Commercial bank of Eritrea (CBE)}

The largest commercial bank in the country, the CBE was established in 1994 and is the sole institution in the country that provides full retail and commercial banking services. The bank is government owned and it is charged with: promotion of savings and provision of credit, promotion of exports, foreign exchange and trade, stimulation of agricultural production and rural development, and financing the working capital requirements of the industrial sector [9].

*Corresponding author: Gvozdanovic I, Department of Finance, Zagreb School of Economics and Management, SMC University, Switzerland, Tel: +385 914555 939; E-mail: igor.gvozdanovic@gmail.com

Received September 09, 2016; Accepted September 21, 2016; Published September 26, 2016

Citation: Gvozdanovic I, Solomon OM (2016) The Effect of Electronic Banking in Financial Supply Chain: E-Banking in Eritrea. J Glob Econ 4: 217. doi: 10.4172/2375-4389.1000217

Copyright: (c) 2016 Gvozdanovic I, et al. This is an open-access article distributed under the terms of the Creative Commons Attribution License, which permits unrestricted use, distribution, and reproduction in any medium, provided the original author and source are credited. 


\section{Housing and commerce bank of Eritrea (HCBE)}

This bank also established in 1994, the HCBE has 9 functional branches and provides housing loans to customers who qualify under the banks credit standards. The bank provides loans for residential and commercial construction, and also for the repair and maintenance of existing buildings. The HCBE also builds and re-sells housing complexes and provides loans to state.

\section{Eritrean development and investment bank}

Though established in 1996, the government owned EDIB began banking operations in 1998 in order to stimulate the country's economic development through mobilization and financing of development-oriented projects in the agricultural, industrial, mining, tourism, construction sectors, among others [9]. The bank offers financing primarily through term lending.

\section{Problem Statement}

In today's modern economies the payment for the goods and services in the supply chain finance is accomplished using e-banking [12]. The developed economies, for instance, European economies are extensively using the advantages of e-banking to gain competitive advantage, reduce their costs, improve their financial services, enlarge their customer databases, and to progress their financial positions [13]. The less developed economies on the other hand, for example subSaharan economies are extremely away from using such advantages due to different problems. This study, therefore, mainly focuses on discovering the applicability and effectiveness of e-banking in resolving the problems of cash flow, liquidity, invoicing, information, communication and other issues related to financial supply chain as well as financial transaction of undeveloped economies like that of Eritrea.

\section{Research Questions}

- How could e-banking facilitate payment and invoicing processes in the supply chain?

- What are the adoption barriers and solutions of internet banking?

- Do banks in less developed countries, like Eritrea have the concept and knowledge of online banking? What about their willingness to adopt the new technology?

\section{Purpose of the study}

The gap of using internet technology in banking system between the developed and less developed economies disadvantaged and marginalized sub-Saharan economies from the global expansion of international trade. The importance of e-banking in assisting Eritrea's supply chain finance on one hand, and sustaining domestic markets on the other hand, are some of the motivating factors to conduct research on the title. Farther, the study also has a focus on the current problems of the industry such as, technological infrastructure, knowledge about the issue, and confidence and fear of risk. Thus, the purpose of this study aims to discover the efficiency of internet banking in financial supply chain under the context of less developed economies along with the following research objectives.

\section{Research objectives}

- To identify the advantages and disadvantages of internet banking in the process of cash flow management along the supply chain.
- To identify the risks and ways of preventing them during adopting e-banking system.

- To identify the basic infrastructure requirements that could facilitate online banking adoption.

\section{Significance of the study}

The application of banking systems in managing financial supply chain in most of Sub Saharan Africa (SSA), remain underdeveloped as compared with other developing regions. According to IMF [14], however, recent developments, such as the expansion of mobile phone-based banking and the spread of pan-African banking groups, have the potential to significantly change the landscape for banking in much of SSA. In Eritrea, the use of online banking in changing the way that companies will interact with their customers, business partners and suppliers is none existent. On top of that, until these days, very little research has been conducted concerning the given topic. An understanding of how internet infrastructure, the knowledge of users and employees of banks, and perceptions and attitudes of community toward e-banking influence the adoption of online banking. It is envisaged that the study will make a theoretical and conceptual contribution to the body of knowledge related to the impact of financial supply chain on international trade with a particular emphasis on banks and entrepreneurs in Eritrea. Therefore it is significant and timely to conduct a research such as this.

Delimitation: The study was limited to the capital city of Asmara. This is because:

- All most all headquarters of banks and companies are located at Asmara, the capital city of the country;

- Main operations and transactions of banks and related financial organizations are finalized at the city;

- The researcher could find the required data for the research without travelling to banks and companies outside the city.

Limitations: Online banking is not yet introduced in the nationEritrea, consequently there is the possibility of information shortage.

- Time and budget constraint;

- The research was done through interviewing selected bank managers, bank employees, business people and researcher's observation. Therefore it may not be possible to generalize the results of this study to all bank workers and entrepreneurs.

\section{Literature Review}

In today's global economy electronic business (e-business) is increasingly become a necessary component of business strategy and a strong catalyst for economic development. Through this strategy that is simple and practicable within the context of a global information era and contemporary digital and economic environment, states, companies, and individuals are able to determine emerging opportunities and utilize the necessary digitalized technologies to make the most of these opportunities.

The rise of the internet as a communication channel has changed the economics of information, gives rise to opportunities, new forms of affiliation, new forms of relationship and new forms of transaction between organizations [14]. Specifically, the use of information and communication technology (ICT) in business has enhanced productivity, encouraged greater customer participation, and enabled mass customization, besides reducing costs [15]. 


\section{The concept of financial supply chain}

The concept of financial supply chain is related to traditional and modern payment systems, supply chain management, and many more factors.

Traditional (TPS) vs modern payment systems (MPS): A conventional or traditional process of payment and settlement involves a buyer-to-seller transfer of cash or payment information (Cheque and credit cards). The actual settlement of payment takes place in the financial processing network in a sense that, cash payment requires a buyer's withdrawals from his bank account, a transfer of cash to the seller, and the seller's deposit of payment to his account [16]. Unlike the traditional system, the modern and sophisticated payment system, where the currency and notes are converted to data, which are in turn transmitted through the telephone lines and satellite transponders is called e-payment system [17]. It is managed by banks under the discipline named financial supply chain (FSC).

Supply chain (SC) and supply chain management (SCM): A supply chain is the network of all the activities involved in delivering a finished product/service to the customer [18]. In this process raw materials are sourced, assembled, stored, ordered, distributed and delivered. Creating an effective supply chain requires: developing strategic objectives and tactics, integrating and coordinate activities in the internal portion of the supply chain, coordinating activities with suppliers and customers, coordinating planning and execution across the supply chain and consider forming strategic partnerships [4].

The vital business function that coordinates all of the network links through supply chain from suppliers to manufacturers to distributors was traditionally called logistics [18]. These days, the term "logistics" is replaced with the more comprehensive term "supply chain management" (SCM) [3]. It is perceived as the task of integrating organizational units along a SC and coordinating materials, information and financial flows in order to fulfill customer demands with the aim of improving competitiveness of the supply chain as a whole [19].

Financial supply chain (FSC) and its management (FSCM): While, the purpose of FSC is to obtain visibility over the purchaseto-order and order-to-cash processes [2], the role of financial supply chain management is simply to manage the financial supply line, now interconnected as a chain, from source to destination and back [3]. Supply chain financing (SCF), relates more specifically to providing the appropriate financing facilities at the relevant points in the physical supply chain [4]. This is to mean that, SCF is "a combination of trade financing provided by a financial institution, a third-party vendor, or a corporation itself, and a technology platform that unites trading partners and financial institutions electronically and provides the financing triggers based on the occurrence of one or several supply chain events [20]".

Effectiveness of FSC and FSCM: There is a diversity of approaches and different frameworks to measure the performance of financial supply chain and its management. As mentioned by Blackman et al. [21], the measurement of operational performance, typically centered on manufacturing and logistics processes such as order cycles and cash flow cycles are well practiced.

\section{The concept of electronic banking (e-banking)}

E-banking is a delivery channel for banking services. Based on the explanation of James et al. [22], electronic banking is a system that is meant to bring the banking services to age and ensure that today's banking services go beyond acceptance of deposit and creation of credit. E-banking includes the systems that enable financial institution customers, individuals or companies to access accounts, transact business, or obtain information on financial products and services through a public or private network, like internet or mobile phone $[23,24]$ (Figure 1).

\section{The concept of adoption of e-banking}

Rapidly growing and changing revolutionized information technologies have overwhelmed the world of financial institutions like banks [25]. The advancement of information technology worldwide has an enormous effect on development of more flexible payment methods and user friendly banking services [26]. These days, electronic banking services are being used with increasing frequency in most continents, including Africa. Factors influencing the adoption of e-banking.

Relative advantage: It is defined as the degree to which a customer believes that using a particular system - which is new to the existing system - would enhance job performance, influencing e-banking adoption positively.

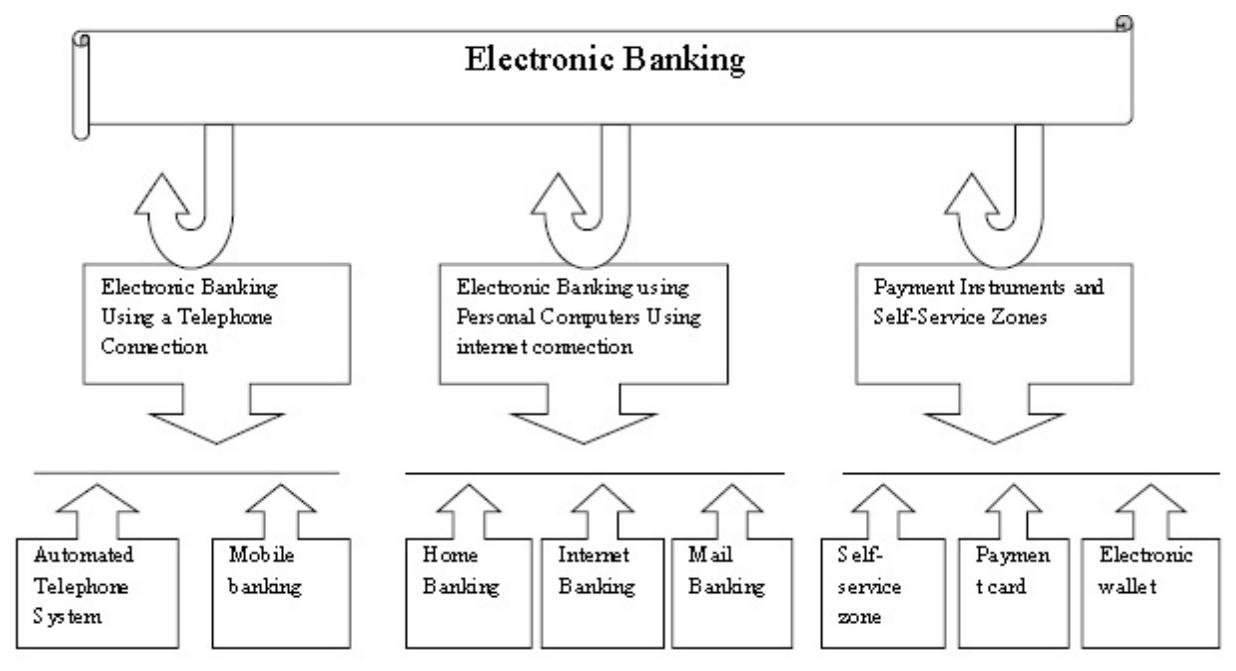

Figure 1: Categories of E-banking [24]. 
Complexity: This attribute is defined by Sabi [27] as the extent to which an innovation can be considered relatively difficult to understand and use. For instance, banks website designs should be very simple by which customers can easily operate (ease of use) [26].

Perceived credibility: It is the degree to which a user feels the certainty and pleasant consequences of using an electronic application service, perceiving that; financial, physical, functional, social, time-loss, opportunity cost, and information risks are nonexistent [28].

Trialability: Refers to the capacity to experiment with new technology before adoption [27]. This helps potential adopters who are allowed to experiment with an innovation to feel more comfortable with it and are more likely to adopt it.

Perceived risk: This attribute refers to the degree of risks or trust (willingness to rely) in using an innovation [26].

Compatibility: Refers to the degree to which a service is perceived as consistent with users' culture [27]. That is, with existing values, beliefs, habits and present and previous experiences of users.

\section{Research Methodology}

\section{Study design}

The aim of this study is to examine the impact of electronic banking on supply chain finance of organizations operating under less developed economies with a specific emphasis on sub-Saharan economies, taking Eritrea as a case study. For this purpose a qualitative rather than a quantitative research method of investigation is chosen. As part of the qualitative approach to the study using secondary data analysis methods and conducting necessary interviews with bank as well as company managers in Eritrea, the researcher includes his own observation of the systems and technologies of the financial institutions, companies and other concerning organizations use to make their international financial transactions and payments.

Data collection methods: Even though, both primary and secondary data was used in the research; there is heavy reliance on the primary one. Data was collected through interviews based on open-ended questions, dichotomous and Multichotomous questions. Influential bank officials, knowledgeable staffs and bank customers (company managers) are selected to be interviewed and form a sample size of 35 using the technique specified below. The list of banks under study includes, National Bank of Eritrea (NBE) which acts as a central bank, Commercial Bank of Eritrea (CBE), Housing and Commerce Bank of Eritrea (HCBE), and the Investment and Development Bank of Eritrea (IDBE).

Target population and sample size: In conducting this research, the managers or staffs of the selected banks and the customers (company managers/owners) are the two target populations under study. It must be noted that these banks offer only traditional banking systems.

The sample size for each of the category or group was determined with deVaus formula below sited by Emmanuel [29]:

$$
n=\underline{\mathrm{N}}
$$

$$
1+N\left(\propto^{2}\right)
$$

Where, $\mathrm{n}=$ sample size, $\mathrm{N}=$ population universe and $\propto$ is the confidence level. The formula adopted a confidence level of $90 \%$ and the margin of error is therefore $10 \%$ which is acceptable in social science research. The break down for each of the group is calculated as follows:
Bank officials (Staffs): where $\mathrm{N}=15$

$\mathrm{n}=15 /\left(1+15\left(0.1^{2}\right)\right)$

$\mathrm{n}=15 / 1.15=13.04 \sim 13$

Thus, $\mathrm{n}=13$

Bank Customers: Where, $\mathrm{N}=28$

$\mathrm{N}=28 /\left(1+28\left(0.1^{2}\right)\right)$

$\mathrm{n}=28 / 1.28=21.87 \sim 22$

Therefore $\mathrm{n}=22$.

Sampling technique: In qualitative research approach, 'purposive' rather than 'random', sampling technique is most often practiced. A good knowledge of this type of sampling strategy and why it is used is necessary to designing a credible qualitative study. In this research, for bank customers, about 10 local companies which are direct customers to the banks and having activities related to international banking transactions are selected. At least 2 respondents (general managers and financial managers) for each company were sampled, making twenty two (22) interviewees. Similarly, influential bank officials and knowledgeable staffs from each bank are selected to be interviewed and form a sample size of 13 . The purpose was to find out the effect of modern banking system on the company's international as well as local payments when they procure goods for their factories and to know the readiness of the banks to adopt e-banking as a business and as a solution to financial supply chain problems.

Data analysis: The analysis of each transcribed interview will follow the process of data reduction, data display and the drawing of conclusions using the outline provided by Miles et al. [30]. The technique of data reduction helps to select, arrange, refine, focus and summarize the data for analysis.

Construction of the final interview guide questions: In this research there are two target groups selected (bank staff and bank customers). Both groups are believed to reflect and provide sufficient and reliable data which can help to analyze the topic under study. Based on the nature of the target population two interview guides are prepared.

- Interview guide 1: The purpose of the questions in this guide is to collect data from staff of knowledgeable employees of the bank. The guide has 6 major topics having 5 questions each. See Appendix A.

- Interview guide 2: It has similar arrangements as guide 1. The aim of the questions is to understand customers' perception on banking systems, financial transactions and existing problems with their solutions. See Appendix B.

Quality data: Reliability and validity: Validity and reliability constitute the credibility of a study. In order to improve the validity of this study, the data was directly gathered with a well calculated approach to sampling and the interviews of banking staff and customers addressed the issues raised in the research questions. Moreover, to increase the reliability of the study, concepts and existing theories were reviewed and carefully defined, presented and compared based on the literature review.

\section{Results}

Based on the interview guide questions and research questions the arrangement of the data presentation is in accordance to: means 
of payment, electronic infrastructure of the banks, knowledge and capability, security and e-banking adoption. The results include the perspectives of bank staffs and bank customers respectively. The researcher interviewed a total of 10 individuals who have worked for more than 15 years at the banking industry and 16 company managers, since he believed that a total of 26 respondents are enough for the required data. In other words, the data reached saturation point (ideas started to be repeated).

\section{Bank staffs perspective}

Means of payment: As most staffs (8 out of 10) of the banks, noted the means of payment practiced in all the banks is using cheque, cash and transferring using letters from account to account. They explained that even the payment by the use of cheque is at its earliest stage, majority of their customers are not familiar with this system and they prefer to use cash to pay for every transaction they do. One of the respondents mentioned "Our banking payment system is absolutely traditional". There is no a system where electronic payments such as internet or online banking could be supported (Table 1).

Electronic infrastructure of the banks (e-infrastructure): Nine out of ten, officials of the banks explained that e- infrastructure of their banks, as it is nonexistent. One respondent underlined saying that, even the computer processer that he is using is Pentium 3, which is almost outdated in the rest of the world. Most of the banks have internet connection, even though it is too slow, irregular, and in inconvenient (Table 2).

Knowledge and capability: Regarding this criteria most of the interviewees ( 8 out of 10) mentioned that their banks often employ either university or college graduates. Most of them ( 7 out of 10) also, agreed that, the workers lack practical training and continuous upgrading courses, even though they know the system theoretically. One of them highlighted "at the moment the capability of the existing manpower of his bank to go with modern banking systems is not qualified, unless they are trained and get chance to practice it".

Security: The security of transacting on the internet is a major concern in adopting internet banking and it needs awareness of the public as well as bank employees to facilitate the adoption process. Assessment of the apprehension of bank officials in using internet banking indicates that, they would not abstain from using modern banking systems, fearing from hackers or crackers. This idea was supported by all interviewees.

Adoption of E-banking: Eight respondents highlighted that, since the initial investment such as introducing an efficient internet service requires huge investment and permission from the government, the initiative action is left on the hands of the government. Table 3 shows the ranks of adoption barriers, where 1 represents the strongest barrier and 5 represents the weakest or having lesser impact to adoption.

\section{Bank customer's perspective}

Means of payment: The types of payments through, cash, cheque, and transfer from account to account are practiced by all companies as all interviewees said. Ten out of sixteen (10/16) respondents added that they also practice Telegraphic Transfer System (TTS), Letter of Credit (LC) and Society for Worldwide Interbank Financial Telecommunication (SWIFT) techniques when they have to pay for an international transaction and remote areas assisted by a bank. While, NBE, CBE and HCBE fully uses the payment techniques of TTS, LC and SWIFT, the IDBE uses only TTS

Electronic infrastructure of the banks: Almost all of the customers of the four banks agreed that, they get inefficient, time consuming and costly services from the banks (NBE, CBE, HCBE and IDBE). They explained the advantages of modern banking infrastructure saying "had our banks been equipped with modern e-banking infrastructures, such that computerized and networked, we would never try to have unnecessary amount of cash at hand, since it facilitates the payment". They prefer to withhold too much amount of cash at hand, just to facilitate their payments on time when they have local business transactions. This represents to 15 respondents out of 16 .

Knowledge and capability: 13 out of 16 bank customers gave their optimistic perspective on knowledge and capability of young generation. They have no doubt about human capital. They just highlighted, that new and existing graduates need to be trained, motivated and should be exposed to new technologies. The rest 3 respondents on the other hand, have an opposite point of view. They say that, most of the bank employees as well as the managers are aged and they are computer illiterate, so they can resist the introduction of modern banking systems.

\begin{tabular}{|l|c|c|c|}
\hline \multicolumn{1}{|c|}{ Payment Type } & $\begin{array}{c}\text { Bank Eritrea } \\
\text { Central B. }\end{array}$ & Commercial Bank & Housing Bank \\
\hline Cheque & $\sqrt{ }$ & $\sqrt{ }$ & $\sqrt{ }$ \\
\hline Cash & $\sqrt{ }$ & $\sqrt{ }$ & $\sqrt{ }$ \\
\hline Letter of Credit (LC) & $\sqrt{ }$ & $\sqrt{ }$ \\
\hline Telegraphic Transfer (TT) & $\sqrt{ }$ & $\sqrt{ }$ \\
\hline SWIFT & $\sqrt{ }$ & $\sqrt{ }$ & $\sqrt{ }$ \\
\hline E-payment (Using Internet) & $X$ & $X$ & $X$ \\
\hline
\end{tabular}

Source: Authors' field survey March, 2016

Table 1: Types of payment services in banks of Eritrea

\begin{tabular}{|c|c|c|c|c|c|}
\hline $\begin{array}{l}\text { Information and Communication Technology } \\
\text { (ICT) tools }\end{array}$ & $\begin{array}{l}\text { Bank Eritrea } \\
\text { (Central B.) }\end{array}$ & Commercial Bank & Housing Bank & Investment Bank & Remark or Status \\
\hline Access to internet and computers & $\sqrt{ }$ & $\sqrt{ }$ & $\sqrt{ }$ & $\sqrt{ }$ & Very weak \\
\hline Automatic Teller Machine (ATM) & $x$ & $\mathrm{x}$ & $x$ & $\mathrm{x}$ & Not, yet introduced \\
\hline Automatic Telephone System (ATS) & $\mathrm{X}$ & $\mathrm{X}$ & $\mathrm{X}$ & $\mathrm{X}$ & Not, yet introduced \\
\hline Office equipments & $\sqrt{ }$ & $\sqrt{ }$ & $\sqrt{ }$ & $\sqrt{ }$ & Inadequate \\
\hline Networking (Server managed) Systems & $\sqrt{ }$ & $\sqrt{ }$ & $\sqrt{ }$ & $\sqrt{ }$ & Only within a bank \\
\hline
\end{tabular}

Source: Authors' field survey March, 2016

Table 2: Technological infrastructure of the banks. 


\begin{tabular}{|l|c|}
\hline Barriers to Adoption & Rank \\
\hline Security and risk issues & 5 \\
\hline Poor technological infrastructure & 3 \\
\hline No Government motivation and initiative & 1 \\
\hline Human capital & 4 \\
\hline Capital Budget & 2 \\
\hline
\end{tabular}

Source: Authors' field survey March, 2016

Table 3: Factors influencing e-banking adoption bankers' perspective.

\begin{tabular}{|l|c|}
\hline Barriers to Adoption & Rank \\
\hline Security and risk issues & 5 \\
\hline Poor technological infrastructure & 2 \\
\hline No Government motivation and initiative & 1 \\
\hline Human capital & 4 \\
\hline Capital Budget & 3 \\
\hline
\end{tabular}

Source: Authors' field survey March, 2016

Table 4: Factors influencing e-banking adoption customers' perspective.

Security: Regarding the security issue, most of the respondents believe that the opportunity created by globalization created confidence on bank users. They just are waiting the introductions of modern banking systems, believing that the system would be adopted with its security and protective measures. Appreciating this idea, a respondent stated "we are not at the lead we are at the tail, so that our banks are fortunate enough, since they can use e-systems which are practiced and modified several times. While 14 respondents agree with this concept, only 2 interviewees disagree and said that face to face (physical involvement) payment methods are the only safest one in our society.

Adoption of e-banking: The availability and frequent use of fast internet connection is necessary for a successful adoption of e-banking. When respondents were asked if the process of e-banking adoption is easy or dificult, most of the respondents (12 out of 16) agreed that, building the infrastructure of fast, frequent, and convenient internet connection as a communication tool is what makes it difficult. Once, such an infrastructure is set and insured its sustainability, it is easy to introduce e-banking. On the other hand few of the respondents (4 out of 16) have the perception that, theoretically our youths are familiar with the idea and concept of modern banking systems and its benefits, eventhough the older people could resist. One respondent revealed "for a successful adoption the process should be gradgual. Meaning, instead of introducing high tech systems at the beging, the banks should adopt step by step starting from moderate, but compatible technologies. Customes ranked the following adoption barrier factors as in Table 4, based on the factors role in adoption. Where, 1 is the most (strong) and 5 is the least (weakest) barrier.

\section{Discussion}

\section{Bank staff's perspective (with-in case analysis)}

Means of payment: Sumanjeet [16] described that the actual settlement of payments in the traditional system takes place using cash, cheque and transfers in the financial processing network. In the same way almost all bank staffs participated in the study stated that cash, transfer and cheque consecutively are the means of payments their banks use. Table 1 shows the types of payment services offered by all the four banks in the country.

Electronic infrastructure of the banks: In Eritrea one of the main challenges in the banking system is the existing e-infrastructure. It is outdated and incompatible with modern systems as stated by the 9 respondents. This agrees with what Dixit and Datta [26] said. Most bank staffs interviewed explained that internet banking is still not in the plan of their business. This suggests that the banks are not on track to introduce modern infrastructure to support their banking system.

Knowledge and capability: E-banking, especially internet banking is highly influenced by employees competence. Interviewed bank officials believe that knowledge and practical training of bank employees is one of the main factors influencing e-banking adoption. The results on this factor by respondents show that, most of the bank employees lack knowledge of IT and e-business, practical training and familiarity with modern technologies, although most of them are computer literate and fast learners.

Security: The issue of security influences the quality of banking service to a great extent, even though it depends on the skill and experience of bank employees as well as its technological infrastructure. This idea is supported by Maduku [31], Shannak [32], Qin Su and Jun $\mathrm{Su}$ [33], and Koskasas [34]. Similarly, most of the interviewed bank officials said that, they have the theoretical know how about banking security and risk (Table 3 ).

Adoption of e-banking: The main problem that can be mentioned here as highlighted by most of the respondents is the quality of the internet service. It is too slow and inconvenient to use it as a communication tool in the banking sector. The only way this service could be improved is through government investment, since it demands huge investment and political decision. The list in Table 3 shows the rank of barriers to adoption.

\section{Bank customers' perspective (with in case analysis)}

The customers of the bank like companies, individuals, governmental agencies, NGOs, and social community associations have their own influence and knowledge of the banking environment. Thus, their point of view is included in this study in the same way as the banks are represented.

Means of payment: According to respondents, every activity performed in the bank is supported by tedious paper works and oblige customers to appear physically at the bank. Customers use cash, cheque, etc. either to deposit, with draw or transfer cash from account to account as a means of payment. The services listed in Table 1 resembles with methods of payments practiced in the traditional bank's activities.

Electronic infrastructure of the banks: The banking industry in Eritrea is a service industry crucial to the growth of its economy. However, interviewed bank customers criticized the technological infrastructure of the banks. They explained that their companies face so many challenges, such as costs, just due to delays created by the banks in accomplishing their financial transactions.

Knowledge and capability: According to the understanding of the respondents, skilled manpower is not a problem in the banks. See the rank of human capital at Table 4. Thus, skill and knowledge is not a factor that could delay the adoption of e-banking.

Security: Based on the studies conducted by Jalal et al. [28] Dixit and Datta [26]; and Sabi [27], the issue of security and risk was identified as a main barrier to adoption of e-banking. This is in contrary to what was found in this research. Simply this means bank customers have no fear of risk, because they believe that the adoption of modern banking technological infrastructure is supported by modern and safe protection mechanisms to risk and fraud. 
Adoption of E-banking: Reasons given by bank customers during interviews for introducing e-banking included fast internet connection, compatible banking infrastructure, practical training and gradual introduction of the system.

\section{Cross case analysis}

Means of payment: Bank staff and bank customers mentioned that, the payment system practiced by all banks is dominated by cash in cash and to some extent by cheque. In their opinion, the system is in its traditional mode and there are no modern e-systems yet introduced to facilitate payment transactions.

Electronic infrastructure of the banks: The bank customers demand the introduction of modern banking system without preconditions. Bank staffs' perspective, in the other way, shows that they still have no plan to modernize their banking system, even though they believe immediate renovation is the only solution. The importance of modern e-infrastructure has presented by several researchers in their previous researches.

Knowledge and capability: Both groups perceive that, even though, the younger employees are computer literate and fast learners of the contemporary banking technology, they need to be supported by continuous training to new technology, practical exposure and on the job training, motivation, empowerment, providing responsibility and accountability.

Security: While, bank officials consider security and risk issues require highly skilled man power and sophisticated technological infrastructure to provide quality services, bank customers in the same way explained that they don't fear from risk, since they believe that the adoption of the system is accompanied by modern protective mechanisms.

Adoption of e-banking: As, Dixit and Datta [26], described, the advancement of information technology worldwide has an enormous effect on development of more flexible payment methods and user friendly banking services. In the same way, both respondents in this study also explained their expectation that the adoption of advanced banking services in Eritrea could assist them in solving problems and challenges existing in payment transactions in the financial supply chain.

\section{Recommendations}

Recommendations are made in line with the factors influencing the process of e-banking adoption: Relative advantage, complexity, perceived credibility, trial ability, perceived risk and compatibility.

Relative advantage: Based on the conclusions drawn from this study, e-banking has relative advantage in improving service quality in the financial supply chain, when compared with the traditional banking system. Thus, bank officials should work hard in influencing decision makers' awareness in order to take a step to introduce electronic banking.

Complexity: While, complexity negatively influences the adoption of e-banking, ease of use affects it positively. The status of the banks under study is identified that they are absolutely traditional. Therefore, the process of adoption of e-banking should take place step by step, since a new innovation could be difficult to understand and use.

Perceived credibility: Banking services provided by the means of modern information technology systems are new to users. At this stage bank managers and concerning bodies should contribute their effort to make users feel the certainty and pleasant consequences of using an electronic application service, at least conceptually.

Trialability: Trialability helps potential adopters who are allowed to experiment with an innovation to feel more comfortable with it and are more likely to adopt it. In the case of Eritrea, a pilot project e-bank should be implemented as soon as possible. This would help, firstly to give chance for banks to practice and train their staff, secondly to assist and experience higher bank officials their managerial skills and thirdly it builds confidence and awareness of customers.

Perceived risk: It is particularly important that banks in Eritrea which are intending or planning to provide e-banking products and services ensure that the privacy and security of their banking customers are effectively guaranteed. This will embolden potential customers to motivate and invest (knowledge or capital) in the process of adoption.

Compatibility: The process of transforming the system of the banks from traditional to modern type is influenced by so many factors, such as culture for instance banking culture. Thus, in adopting e-banking in the country, it is necessary to study user requirements and needs, since the feature of innovation as conformance with user's lifestyle can propel a rapid rate of adoption.

\section{Conclusion}

To summarize, all the objectives and research questions of this study were successfully achieved. With respect to the process of e-banking adoption the following challenges were identified. Firstly, government initiatives to invest in the e-infrastructure such as internet connectivity, sustainable supply of energy and permitting e-banking services in the banking sector, which have an impact on solving financial supply chain problems. Since all the banks in the country are government owned, the initiative mainly depends on the government. Secondly, yet there is no known plan to invest or initiate modern banking systems. Known plan of action might give light to help bank managers to prepare their organization for transformation. Finally, since the working environment of all banks in Eritrea is absolutely traditional, transformational process could not be achieved easily. It requires huge investment.

\section{References}

1. Popa V, Barna M (2013) The financial supply chain management. Supply Chain Management Journal.

2. Kristofik P, Kok J, Vries S, Sten-van't Hoff J (2012) Financial supply chain management-challenges and obstacles. ACRN Journal of Entrepreneurship Perspectives 1: 132-143.

3. Goh M (2013) Supply chain connectivity and trade in Asia.

4. Truel C (2008) Supply chain finance 101: Tactics. Supply Business. Reductive Publishing Ltd, London.

5. Carswell K (2007) Supply chain finance: a new way for trade banks to strengthen customer relationships.

6. Sarma G, Singh P (2010) Internet banking: risk analysis and applicability of biometric technology for authentication. Int J Pure Appl Sci Technol 1: 67-78.

7. Paper W (2013) The bank payment obligation: a new payment term to secure and finance trade. SWIFT.

8. Pandian RD (2013) An analysis of effective financial supply chain management International Journal of Advanced Research in Management and Social Sciences 2: 202-219.

9. Johanson D (2014) Diplomacy in act: investment climate statement

10. Healy S (2007) Eritrea`s economic survival: Summary record of a conference held on 20th April. The Royal Institute of International Affairs. 
Citation: Gvozdanovic I, Solomon OM (2016) The Effect of Electronic Banking in Financial Supply Chain: E-Banking in Eritrea. J Glob Econ 4: 217. doi: $10.4172 / 2375-4389.1000217$

Page 8 of 8

11. Nyende M, Okumu L (2014) African economic outlook: Eritrea.

12. Michael I, Gary P (2012) Modernize or fail: the modernization challenges facing banks and the technology implications. Oracle financial services.

13. International Monetary Fund (IMF) (2013) Banking in Sub-Saharan Africa: the macroeconomic context. Washington DC, IMF.

14. Luqman A (2011) E-business adoption amongst SMEs: a structural equation modeling approach. J Internet Bank Commer.

15. Ruth ZB (2003) E-commerce and e-business.

16. Sumanjeet S (2009) Emergence of payment systems in the age of electronic commerce: The state of art. Asia Pacific. Journal of Finance and Banking Research.

17. Chavan J (2013) Internet banking: Benefits in an emerging economy. International Journal of Research in Business Management 1: 19-26.

18. Lindeke RR (2014) Supply chain management.

19. Mazlan R, Ali NK (2006) Relationship between supply chain management and outsourcing.

20. Paper W (2007) Supply chain finance: A new way for trade banks to strengthen customer relationships. CGI Group Inc.

21. Blackman DI, Holland PC, Westcott T (2013) Motorola's global financial supply chain Strategy UK Supply Chain Management. An International Journal 18: $132-147$

22. James Sunday K (2014) The E-Banking system: the dynamism of financial transparency and globalization. An Online International Research Journal.

23. Zimucha T, Zanamwe N, Maduku T, Mapungwana P, Chakwizira E, et al.
(2012) An evaluation of the effectiveness of e-banking security strategies in Zimbabwe: a case study of Zimbabwean. J Internet Bank Commer.

24. Chovanová A (2006) Forms of electronic banking. Narodna Banka Slovenska.

25. Ismail MA, Osman MA (2012) Factors influencing the adoption of e-banking in Sudan: perceptions of retail banking clients. J Internet Bank Commer.

26. Dixit N, Datta SK (2010) Acceptance of E-banking among adult customers: an empirical investigation in India. J Internet Bank Commer.

27. Sabi $H$ (2014) Research trends in the diffusion of internet banking in developing countries. J Internet Bank Commer.

28. Jalal A, Marzooq J, Nabi HA (2011) Evaluating the impacts of online banking factors on motivating the process of e-banking. Journal of Management and Sustainability.

29. Emmanuel A (2011) The effect of internet banking on the Ghanaian banking industry: a case of Call Bank, Uni Bank and Prudential Bank. Commonwealth.

30. Miles M, Huberman A (1994) Qualitative data analysis: An expanded sourcebook.

31. Maduku DK (2013) Predicting retail banking customers' attitude towards Internet banking services in South Africa. Southern African Business Review.

32. Shannak RO (2013) Key issues in e-banking strengths and weaknesses: the case of two Jordanian banks. European Scientific Journal.

33. Qin Su Y, Jun Sun Y (2012) Analysis of SWOT on Internet Banking. Advances in Applied Economics and Finance.

34. Koskosas I (2011) The pros and cons of internet banking: a short review. Business Excellence and Management. 